\title{
Didelphidae marsupials (Mammalia, Didelphimorphia) from the Late Pleistocene deposit of the Gruta dos Moura Cave, northern Brazil
}

\author{
PATRICIA VILLA NOVA ${ }^{1,2}$, LEONARDO S. AVILLA ${ }^{1,2}$ and ÉDISON V. OLIVEIRA ${ }^{3}$ \\ ${ }^{1}$ Programa de Pós-Graduação em Ciências Biológicas, Biodiversidade Neotropical, Universidade \\ Federal do Estado do Rio de Janeiro, Av. Pasteur, 458, Urca, 22290-255 Rio de Janeiro, RJ, Brasil \\ ${ }^{2}$ Laboratório de Mastozoologia, Departamento de Zoologia, Instituto de Biociências, Universidade \\ Federal do Estado do Rio de Janeiro, Av. Pasteur, 458, Urca, 22290-255 Rio de Janeiro, RJ, Brasil \\ ${ }^{3}$ Laboratório de Paleontologia, Departamento de Geologia, Universidade Federal de Pernambuco, \\ Av. Acadêmico Hélio Ramos, s/n, Cidade Universitária, 50740-530 Recife, PE, Brasil
}

Manuscript received on May 27, 2014; accepted for publication on July 29, 2014

\begin{abstract}
The present study acknowledges the diversity of fossil marsupials from the Gruta dos Moura cave, as well as environmental and climatic aspects during the Quaternary. The results show that this is the largest diversity of Pleistocene marsupials recorded in a single cave: Didelphis albiventris, D. aurita, Gracilinanus agilis, G. microtarsus, Marmosa murina, Monodelphis brevicaudata, M. domestica and Sairadelphys tocantinensis. Furthermore, the described specimens are also part of the only fossil assemblage unequivocally referable to the late Pleistocene. Paleontological studies suggest an intimate association with dry and open environments with high abundance of water sources. Since most of the identified taxa are characteristic of open forests and gallery forests, this could represent the actual environment around the Gruta dos Moura cave. Recent studies identified sympatric occurrences between species from open and dry environments and species from humid forests that were identified among our material and are characteristic of humid regions. Therefore, these species could inhabit gallery forests and capons, or even ecotones, inside a dry and open environment. Moreover, the extinction of Sairadelphys could also indicate that the climatic and environmental conditions changed or that the past environment was more heterogeneous than the current environment of the region.
\end{abstract}

Key words: mammals, Didelphidae, marsupials, Northern Brazil, Quaternary, Late Pleistocene.

\section{INTRODUCTION}

Extant South American marsupials are included in two lineages: Ameridelphia and Australidelphia. While Ameridelphia is highly diverse in this continent, Australidelphia is represented only by the microbiotherid Dromiciops gliroides (Aplin

Correspondence to: Patrícia Villa Nova

E-mail: patriciavp89@gmail.com and Archer 1987). Ameridelphia is represented by three lineages that diverged during the Paleocene, and has great stratigraphic distribution, large variety of forms, sizes, and feeding habits (Pascual 1980, Oliveira and Goin 2006). In this contribution we studied the family Didelphidae, which contains species from small to medium sizes that are usually arboreal, and of omnivorous, insectivorous, 
piscivorous and frugivorous diets. The first records of didelphid marsupials are from the late Cretaceous of North America, and from the Paleocene of South America (Pascual 1980). During the Miocene the Didelphidae became extinct in North America but reoccupied that continent during the Great American Biotic Interchange (Reig et al. 1987, Marshall et al. 1990).

Many genera of living Didelphidae are also found as fossils at Neogene and Quaternary deposits from Argentina, Brazil and Colombia (Goin 1995). The oldest didelphid taxa with living representatives are recorded in the middle Miocene of La Venta, Colombia, and comprise three species: Thylamys minutus, Thylamys colombianus and Micoureus laventicus (Goin 1995). Another Neogene taxon, the new species Didelphis solimoensis, from the late Miocene of Formação Solimões, state of Acre, northern Brazil, is the oldest representative of this genus (Cozzuol et al. 2006).

The diversity of Didelphidae from the Brazilian Quaternary is well represented from karstic caves. Among the Brazilian karstic caves containing Quaternary fossils, the caves from Lagoa Santa, state of Minas Gerais, were studied by a Danish researcher, Peter Wilhelm Lund (Lund 1950). The fossil materials collected by Lund were sent to the Natural History Museum of Denmark, where the marsupial fossils were described by Winge (1893), who identified thirteen species representing the largest association diversity of fossil marsupials found until now (Cartelle 1999). The second largest assemblage of didelphids from the Brazilian Quaternary described in the literature is from Serra da Mesa, state of Goiás (Salles et al. 1999). Eight taxa were described for this region: Monodelphis domestica, Monodelphis kunsi, Gracilinanus emiliae, Gracilinanus agilis, Thylamys sp., Micoureus demerarae, Didelphis albiventris and Philander opossum. Cartelle (1999) also reported some Pleistocene-Holocene marsupials from several caves in Bahia, identifying four species: Didelphis albiventris, Gracilinanus agilis, Micoureus cinereus and Monodelphis domestica.

The whole record of Didelphidae from the Brazilian Quaternary is represented by living genera, except for the new genus and species recently described, Sairadelphys tocantinensis. The specimens representing this new taxon were also collected at a karstic cave located in southeast, state of Tocantins, northern Brazil (Oliveira et al. 2011). In addition to this material, other didelphid taxa were found associated with the specimens of S. tocantinensis, which are described here.

\section{MATERIALS AND METHODS}

LOCALITY AND GEOLOGY

All studied specimens come from a carbonate deposit which was found in a block at the wall of the main room of the limestone cave, Gruta dos Moura, in Aurora de Tocantins (12 $42^{\prime} 47^{\prime \prime} \mathrm{S}$ and $\left.46^{\circ} 24^{\prime} 28^{\prime \prime} \mathrm{W}\right)$, state of Tocantins, northern Brazil. The carbonate rocks of the region of Aurora do Tocantins are part of the Speleological Province of the Bambuí Group, where a large number of caves have been found (Zampaulo and Ferreira 2009). The geology of the studied area is still poorly known. The predominant rocks in the region are rhythmic limestones and siltstones from the Paraopeba Subgroup of Neoproterozoic age, although alluvial deposits might occur locally (Dardene 1978, Dardene and Walde 1979).

The information provided by the Geological Survey of Brazil (CPRM 2006) on the geology of the municipality of Aurora de Tocantins report carbonate and terrigenous deposits. The lower portion of area is represented by the Sete Lagoas Formation, which is composed of thick deposits of mudstones, calcareous and dolomites.. The Sete Lagoas Formation is covered by siltstone and laminate siltstones of the Serra de Santa Helena Formation. This carbonate-terrigenous 
conjunction of rocks is superimposed by dark calcarenites and marls, with organic material from the Lagoa do Jacaré Formation. Superimposed over the Bambuí Group are the Cretaceous sediments of the Urucuia Formation. The caves were developed mainly in the limestones of Lagoa do Jacaré Formation, which consist of slightly weathered dark gray metacalcarenites, massive or with horizontal lamination, with sparry calcite (generally in veins), micritic calcite, ooids and small amounts of silica. In some outcrops there are interbedded metacalcarenites, mudstones and calcilutites. Millimetre- to centimeter-wide whitish gray intraclasts occur throughout the predominant limestones (CPRM 2006).

The limestones often form plateaus that rise from the rest of the terrain and comprise a partially active karst system. Most caves occur above the ground level in high portions of the plateaus. The caves originated during a period of formation of karst relief in which the rocks that now compose the plateaus were below the ground level. The current outcrops were developed not by the uplift of the plateaus, but by the different types of erosion of the limestones and the erosive retraction of the Urucuia sandstones which once covered the region and today occur to the east of the study area. Access to the plateaus occurs mainly through vicinal roads and paths that cut the vegetation. Currently, the region is situated mainly within the Cerrado biome.

The Gruta dos Moura cave is an epigenic, solutional, ramiform to network cave with some branchwork passages (sensu Palmer 1991) and has great vertical and horizontal development. The entire length of the cave has not yet been completely mapped. The Gruta dos Moura cave originated in a phreatic zone and was later invaded and enlarged by vadose water. There is a notable difference between the upper and lower levels of the cave. The higher levels show galleries and fissures with many speleothems, including travertines, draperies, stalactites, stalagmites and coraloids, showing a higher activity of vadose waters. The fossils were found in the lower levels, which consist of phreatic passages and rooms with few speleothems. Slightly consolidated sedimentary deposits outcrop at these levels, composed of massive, very fine to coarse, immature and poorly sorted sands with clayey matrix. In some parts of the cave a relict carbonate precipitation layer can be seen having a rich in millimeter- to centimetersized fragments of bones and teeth. This layer seems to have covered the sedimentary deposits in a period of decreased sedimentation and stagnation of water flow, causing the precipitation of carbonates and concentrating sediment.

The occurrence of sedimentary deposits covered by carbonate incrustation lenses is also observed in many other caves in the region of Aurora do Tocantins, possibly corresponding to a large scale event of increased humidity, causing changes in the pattern of recharge from the land surface and consequently in the entire environment. Similar occurrences were studied by Auler et al. (2009), who identified three processes (clastic sediment input, erosion and calcite deposition) that are linked to distinct palaeoenvironmental and climatic conditions.

The episodes of clastic input would be related to a drier climate, sparse vegetation and intense sediment yield due to runoff, while the precipitation of calcite would be related to wetter conditions (Auler and Farrant 1999, Brain 1995, Brook et al. 1997). Sediment erosion inside those caves can be interpreted as cause of intermediate climatic conditions, which were not humid enough for speleothem deposition and not dry enough to allow transportation of sediment into the caves (Auler et al. 2009).

\section{Methodology}

The fossil remains of Didelphidae were collected from a block of calcareous rock that was water-washed and sieved (screenwashing). The screenwashing 
was made with four sieves with meshes of $10 \mathrm{~mm}$, $5 \mathrm{~mm}, 2.5 \mathrm{~mm}$ and $1 \mathrm{~mm}$. The material kept on the sieves was dried and, later, selected in laboratory using a stereoscopic microscope.

The identification and diagnosis of the specimens from Gruta dos Moura cave were made by morphological comparison of cranial and mandible elements of Didelphidae specimens housed at the following institutions: Fossil Mammal collection of the Mammalogy Laboratory, Universidade Federal do Estado do Rio de Janeiro (UNIRIO), Mammalogy collection of the Museu Nacional, Universidade Federal do Rio de Janeiro, Rio de Janeiro, Brazil (MN/UFRJ); Mammalogy Laboratory, Zoology Department, Universidade Federal de Pernambuco, Pernambuco, Brazil (UFPE); Universidade Federal do Espírito Santo, Espírito Santo, Brazil (UFES); and Museo de La Plata, La Plata, Argentina (MLP).

The dental nomenclature followed Goin and Candela (2004) (Fig. 1). The post-protocrest can be seen on Gracilinanus microtarsus but was not named on figure 1 of Goin and Candela (2004). The acronyms M1, M2, M3 and M4 are used to address the first, second, third and fourth upper molars, respectively; and the acronyms $\mathrm{m} 1, \mathrm{~m} 2, \mathrm{~m} 3$ and $\mathrm{m} 4$ refer to the first, second, third and fourth lower molars, respectively. The deciduous molars are referred to as "dp".

\section{RESULTS}

The methodology described here allowed the recovering of 57 cranio-mandibular specimens with preserved teeth (upper and lower molars) that, after careful identification, revealed five genera and eight species of Didelphimorphia. Therefore, the diversity presented here is comparable to the diversity of didelphids from Serra da Mesa and Lagoa Santa localities, considered the largest records on diversity of didelphids to South America (Salles et al. 1999, Winge 1893). However, it is worth noting that the material studied here

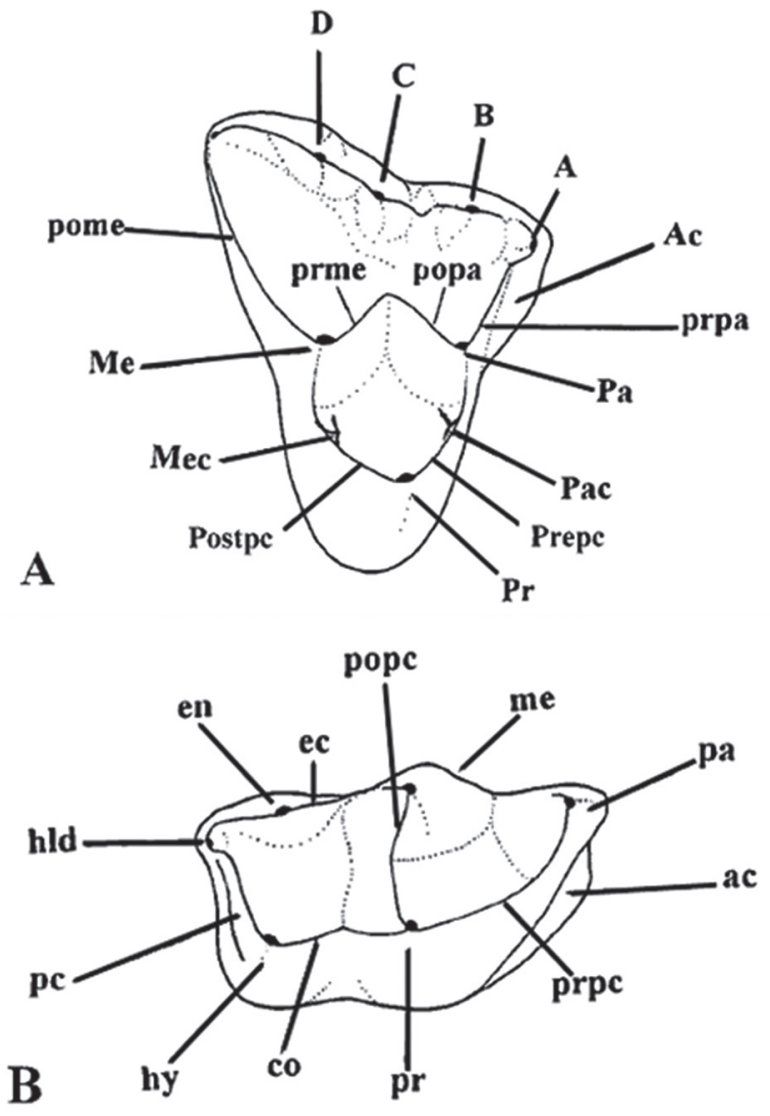

Figure 1 - Nomenclature for didelphimorph molar (modified from Goin and Candela 2004). A. Upper right molar; B. Lower right molar. Abbreviations for upper molars: $\mathrm{A}, \mathrm{B}$, C, D: stylar cusps A, B, C, and D, respectively; Ac: anterior cingulum; Me: metacone; Mec: metaconule; Pa: paracone; Pac: paraconule; pome: postmetacrista; popa: postparacrista; Postpc: postprotocrista; Pr: protocone; Prepc: preprotocrista; prme: premetacrista; prpa: preparacrista. Abbreviations for lower molars: ac: anterior cingulum; co: cristid obliqua; ec: entocristid; en: entoconid; hld: hypoconulid; hy: hypoconid; me: metaconid; pa: paraconid; pc: postcingulum; popc: postprotocristid; pr: protoconid; prpc: preprotocristid.

comes from a single cave, while the Didelphidae diversity from Serra da Mesa and Lagoa Santa were recovered from several caves on each respective locality (Winge 1893, Salles et al. 1999).

\section{SYSTEMATICS}

MAMMALIA Linnaeus, 1758

DIDELPHIMORPHIA Gill, 1872

DIDELPHIDAE Gray, 1821 
Didelphis Linnaeus, 1758

Didelphis aurita (Wied-Neuwied, 1826)

(Fig.2 C-E)

Referred material: UNIRIO-PM1206, left dp3; UNIRIO-PM1207, right dp3; UNIRIO-PM1208, left dp3.

Description and comments: The deciduous molars are broad on its middle-distal portion, labio-lingually compressed, and having inflated cusps. The trigone basin is deep, and the ectoflexus is absent. The most developed stylar cusps are StB and StD. The paracone is very small, and it is fused with the StB. The specimens differ from Didelphis albiventris in having smaller molars. Compared to the deciduous molars of D. marsupialis, the paracone is not as coalesced to the StB as in D. aurita. On Philander, the paracone is aligned with the metacone.

Fossil record in South America: This is the first record of the taxon to the continente (Fig. 2).

Remarks: Didelphis aurita is found in eastern Brazil in the Tropical Atlantic Forest and in the Araucaria Forest domains. Populations of blackeared opossums still occur in the remnants of the Atlantic Forest of Alagoas and Pernambuco, but are considered to be rare (Gardner 2008).

Didelphis albiventris (Lund, 1840)

(Fig.2 A-B)

Referred material: UNIRIO-PM1209, left dentary.

Description: The $\mathrm{m} 1$ is worn. The metaconid is the largest cusp of the trigonid; it is tall, labially displaced, with slender edges. The protoconid is the smallest cusp of the trigonid, and has slender and straight edges. The entoconid and the hypoconulid are very close, and both are distally displaced. The post-hypocristid is rectilinear. The hypoconid is broad and labially displaced. The $\mathrm{m} 2$ is worn on the trigonid, the hypoconid is well developed and distally displaced, and the anterior cingulum is well developed. The $\mathrm{m} 4$ has developed anterior cingulum.
Comments: The lower molars have a shallow talonid, well developed anterocingulid, and hypoconulid distally displaced. The specimen differs from Didelphis aurita, which has the entoconid more set apart from the hypoconulid, and the entoconid is not distally placed. This is particularly evident on the $\mathrm{m} 4$. The material is also distinct from Didelphis marsupialis, since this species has larger molars. The $\mathrm{m} 4$ of D. marsupialis has the entoconid coalesced to the hypoconulid, and in the $\mathrm{m} 3$ the entoconid is much more developed. The dentary is very thick, a feature unusual in living specimens of $D$. albiventris, and has a straight ventral edge. Fossil record in South America: late Pleistocene of Mar Del Plata and Holocene of Córdoba, Argentina; Pleistocene of Lagoa Santa, Minas Gerais and Bahia; Quaternary of Serra da Mesa, Goiás, Brazil (Winge1893, Salles et al. 1999, Cartelle 1999) (Fig. 2).

Remarks: Didelphis albiventris inhabits open and deciduous forest areas, including areas of low and irregular rainfall such as the Caatinga and Monte Desert (Gardner 2008).

Gracilinanus Gardner \& Creighton, 1989

Gracilinanus agilis (Burmeister, 1854)

(Fig.3 A-E)

Referred material: UNIRIO-PM1116, left M1; UNIRIO-PM1117, left M2; UNIRIO-PM1118, left M2; UNIRIO-PM1119; UNIRIO-PM1210, right M1; UNIRIO-PM1211, right M2; UNIRIOPM1212, left M2; UNIRIO-PM1213, left M3; UNIRIO-PM1214, left M3; UNIRIO-PM1215, right maxillary with $\mathrm{M} 2$ and $\mathrm{M} 3$; UNIRIOPM1216, left maxillary with M1-4; UNIRIOPM1217, left maxillary with M3 and M4, right M2; UNIRIO-PM1225, left M3; UNIRIO-PM1226, left M3; UNIRIO-PM1227, right M1; UNIRIOPM1228, left M1.

Description: The M1 and M2 are broader mesiodistally than the M3. The M1 has a well developed preparacrista connected to the StB. The 


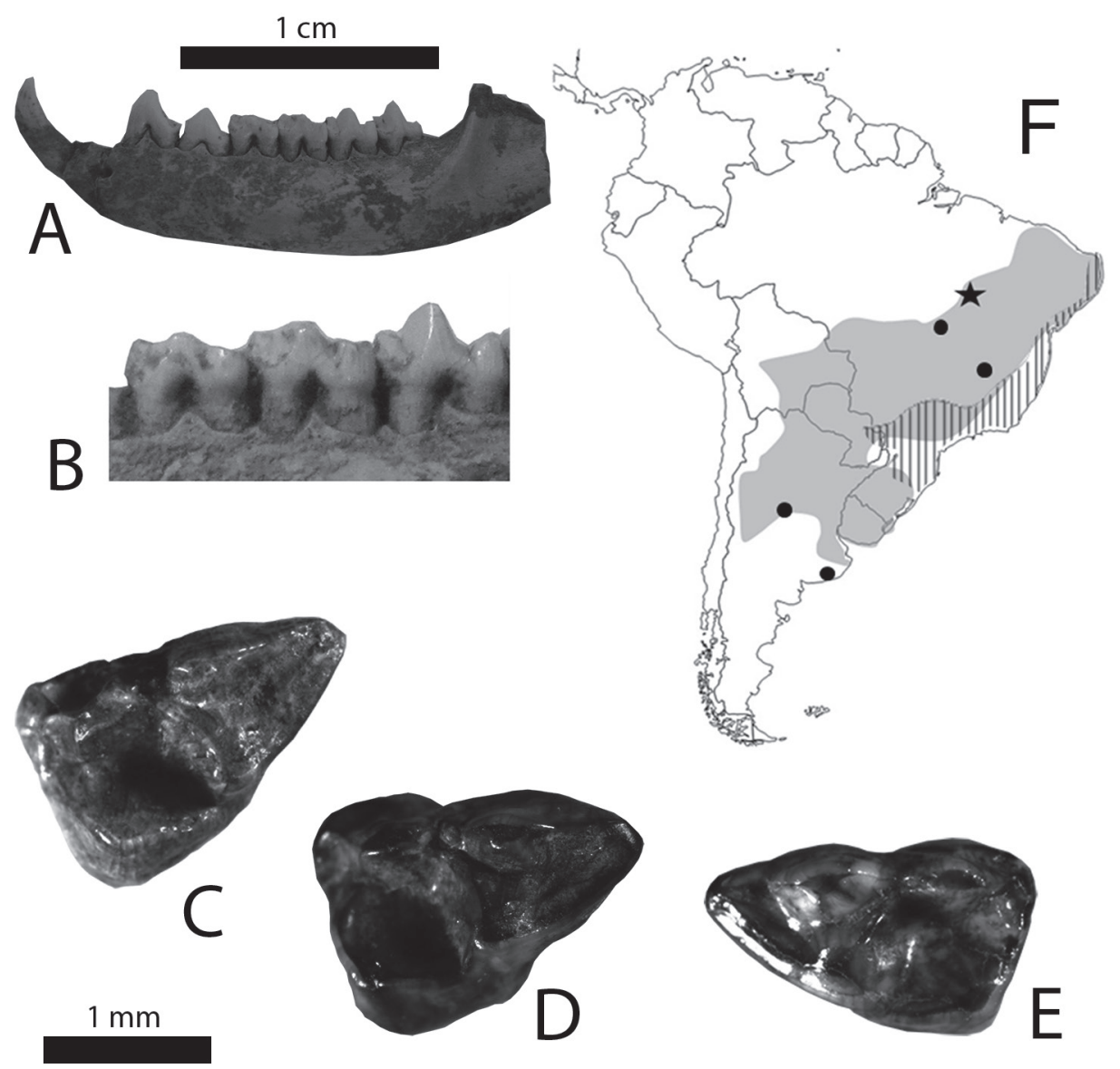

Figure 2 - Selected specimens of Didelphis from Gruta dos Moura and its revised geographic distribution for the Pleistocene. A. An almost complete left dentary of Didelphis cf. albiventris (UNIRIO-PM1209) in labial view. B. A detail view of molar series of the left dentary of Didelphis cf. albiventris (UNIRIO-PM1209) in labial view. Note the great wear mainly in the $\mathrm{m} 1$ and $\mathrm{m} 2$. Scale: $1 \mathrm{~cm}$. C. Left dp3 of Didelphis cf. aurita (UNIRIO-PM1206) in occlusal view; D. Left dp3 of Didelphis cf. aurita (UNIRIO-PM1208) in occlusal view; E. Right dp3 of Didelphis cf. aurita (UNIRIO-PM1207) in occlusal view. Scale 1mm. Geographic F. Distribution of Didelphis aurita and D. albiventris. Gray area is the geographic distribution of the extant Didelphis albiventris. Area with vertical lines is the geographic distribution of the extant Didelphis aurita. Black star marks the Gruta dos Moura cave locality. Black circles mark Pleistocene records of Didelphis albiventris. (Gardner 2008, Winge 1893, Salles et al. 1999, Cartelle 1999).

StB is well developed, and similar in height to the paracone. The M3 is more mesiodistally compressed than the M2. The protocone of the M3 is also very compressed, and the ectoflexus is deep. The M1 has a poorly developed ectoflex, and the M2 has a moderately developed ectoflexus. The stylar shelf is moderately developed. A small $\mathrm{StC}$ is present.
Comments: The material is characterized by the presence of upper molars mesiodistally compressed, small stylar cusps, StC that may or may not be present, and metacone larger than the paracone. The species differs from Gracilinanus microtarsus because the latter has the posprotocrista extended beyond the base of the metacone. This feature is not observed in G. agilis. 
Fossil Record in South America: Pleistocene of Lagoa Santa, Minas Gerais; Quaternary of Serra da Mesa, Goiás and Rio Grande do Sul; Pleistocene of Bahia (Winge1893, Salles et al. 1999, Cartelle 1999, Hadler et al. 2009) (Fig. 3).

Remarks: Living specimens were trapped in disturbed cloud forest characterized by a bamboo (Chusquea sp.) understory and a mossy ground cover. Salazar-Bravo et al. (2002) mentioned trapping a specimen in a habitat consisting of a mixture of pajonales, sphagnum bogs, mixedspecies forest, and Polylepis forest on a "blocky" limestone substrate.

Gracilinanus cf. microtarsus (J.A. Wagner, 1842) (Fig.3 F-H)

Referred material: UNIRIO-PM1218, right M3; UNIRIO-PM1219, right M2.; UNIRIO-PM1220, left M2

Description: The metacone is much larger than the paracone. The stylar shelf and the trigon basin are similar in size. The M2 and M3 have the postprotocrista extended to beyond the base of the metacone. The anterior cingulum is narrow, and it is connected to the preprotocrista. The $\mathrm{StC}$ is present. The left M2 has $\mathrm{StD}, \mathrm{StB}$ and $\mathrm{StC}$ of similar sizes. The protocone is mesiodistally broader. The first upper molars have the protocone labio-lingually compressed.

Comments: Molar teeth are characterized by the postprotocrista extended to beyond the lingual limit of the metacone. This feature is only observed in G. microtarsus, which distinguishes it from other species of Gracilinanus. Some molars have the anterior cingulum connected to the preprotocrista. The material studied differs from Marmosa, which presents more developed anterior cingulum, and has little difference in size between the paracone and the metacone. It is also different from Micoureus, which presents a more conspicuous size difference between the paracone and the metacone. In addition, the molars of Micoureus are labio- lingually compressed, making it broader. Finally, G. microtarsus differs from Thylamys, because the latter has the postprotocrista labially extended.

Fossil Record in South America: Pleistocene of Lagoa Santa, Minas Gerais, Quaternary of Rio Grande do Sul. Brazil (Winge 1893, Salles et al. 1999, Cartelle 1999, Hadler et al. 2009)

Marmosa Gray, 1821

Marmosa murina (Linnaeus, 1758)

(Fig.4)

Referred material: UNIRIO-PM1093, left maxillary with M1-2; UNIRIO-PM1094, right maxillary with M2-3; UNIRIO-PM1219, fragment of right maxillary with M1; UNIRIO-PM1221, right M2; UNIRIO-PM1222, right M3; UNIRIO-PM1223, left maxillary with M3-4; UNIRIO-PM1224, left M2.

Description: The M3 have individualized StB and $\mathrm{StD}$, subdivided $\mathrm{StC}$, marked ectoflexus; paracone and metacone of similar sizes; wide trigone and stylar shelf labio-lingually compressed, well developed protocone anterior cingulum connected with the preprotocrista. At the M1-M2 the StB is individualized. A vestigial metaconule is present (Fig.4A and 4B).

Comments: The molar teeth are characterized by the presence of small and separated $\mathrm{StB}$ and $\mathrm{StD}$; subequal paracone and metacone, well developed ectoflexus and vestigial metaconule eventually present. M. murina differs from Micoureus, which has less developed cingulum, especially at the M4, and also has a more conspicuous difference between the paracone and the metacone. It differs from Gracilinanus, because the latter has molars that are mesiodistally broader, which makes the stylar shelf broader than the trigone. Furthermore, the protocone of Gracilinanus is more compressed. Lastly, Thylamys differs from M. murina, in having labio-lingually compressed molars.

Fossil Record in South America: This is the first fossil record of M. murina (Fig. 4). 

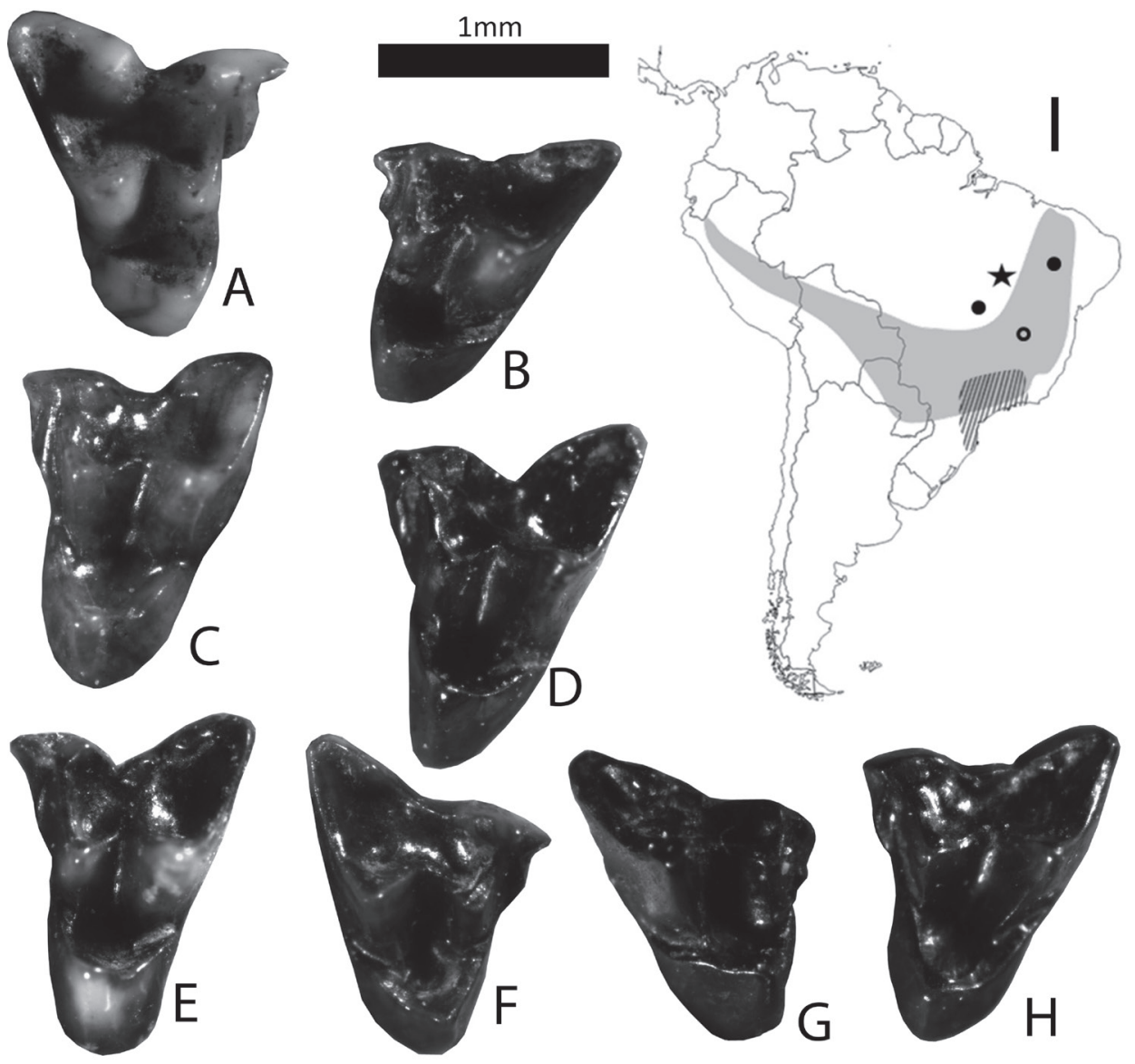

Figure 3 - Selected specimens of Gracilinanus from Gruta dos Moura and its revised geographic distribution for the Pleistocene. A. Gracilinanus agilis right M2 (UNIRIO-PM1211) in occlusal view; B. G. agilis left M2 (UNIRIOPM1118) in occlusal view; C. G. agilis left M2 (UNIRIO-PM1212) in occlusal view; D. G. agilis left M3 (UNIRIOPM1214) in occlusal view; E. G. agilis left M3 (UNIRIO-PM1213) in occlusal view. F. Gracilinanus cf. microtarsus right M2 (UNIRIO-PM1219) in occlusal view; G. G. microtarsus right M3 (UNIRIO-PM1218) in oclusal view; H. G. microtarsus left M2 (UNIRIOPM1220) in occlusal view. Scale $1 \mathrm{~mm}$. I. Geographic distribution of G. agilis and G. microtarsus. Gray area is the geographic distribution of the extant G. agilis. Area with vertical lines is the geographic distribution of the extant G. microtarsus. Black star marks the Gruta dos Moura cave locality. Black circles mark Pleistocene records of G. agilis. Open circle mark Pleistocene records for both G. agilis and G. microtarsus. (Gardner 2008, Winge 1893, Salles et al. 1999, Cartelle 1999, Hadler et al. 2009).

Monodelphis Burnett, 1830

Monodelphis brevicaudata (Erxleben, 1777) (Fig.5 A-D)

Referred material: UNIRIO-PM1095, right M1; UNIRIO-PM1096, left M1; UNIRIO-PM1097, left M1; UNIRIO-PM1098, right M1; UNIRIOPM1099, left maxillary with M1-2; UNIRIO-
PM1229, left maxillary with M1-3; UNIRIOPM1230, left M2; UNIRIO-PM1231, left M1; UNIRIO-PM1232, left M1.

Description: The M1 has a labio-lingually compressed protocone while the M3 presents a mesio-distally compressed protocone. The StD is the largest cusp in all molars. The ectoflexus is 


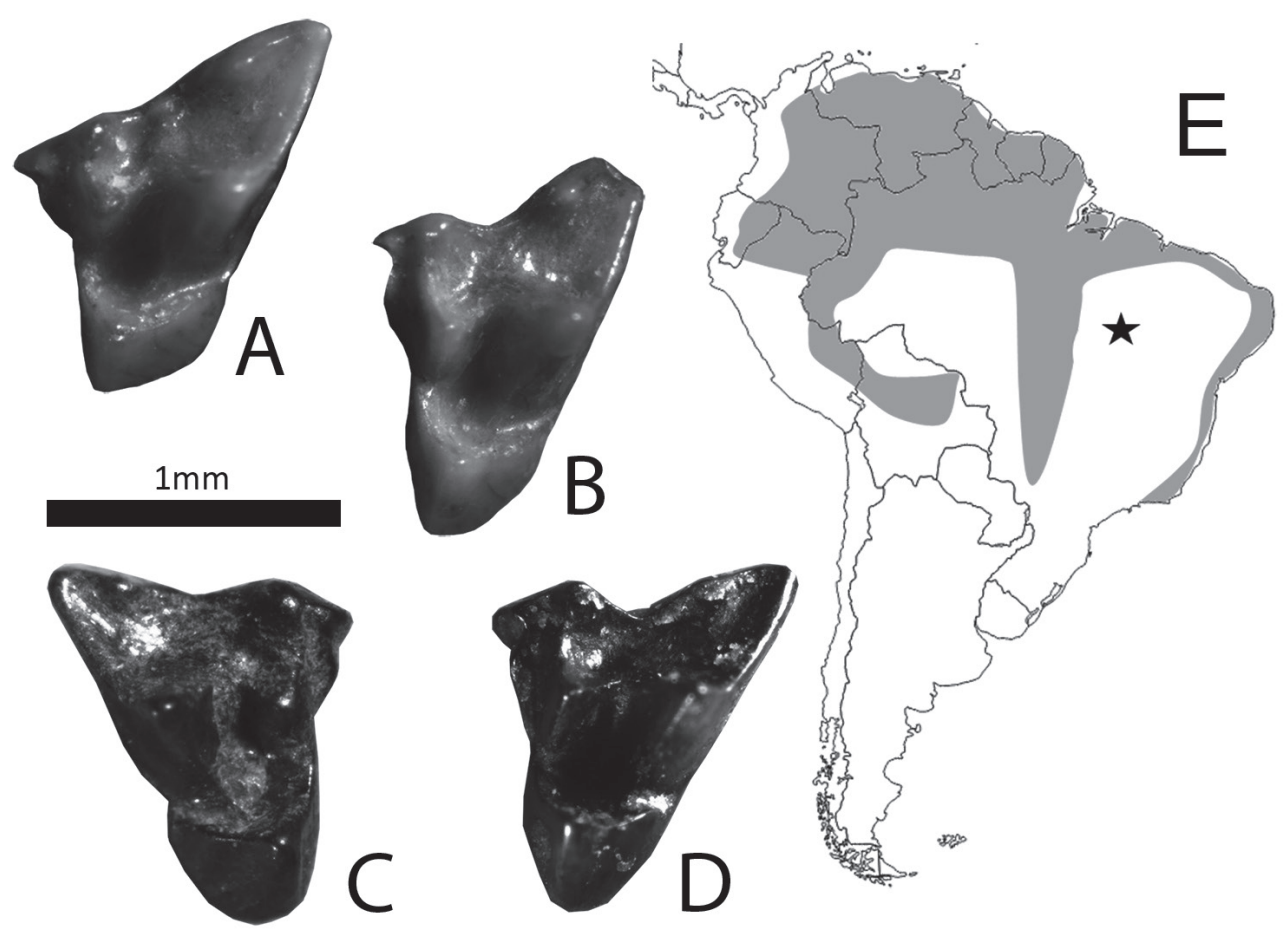

Figure 4 - Selected specimens of Marmosa murina from Gruta dos Moura and its revised geographic distribution for the Pleistocene. A. Left M1 (UNIRIO-PM1093) in occlusal view; B. Left M2 (UNIRIOPM1093) in occlusal view; C. Right M3 (UNIRIO-PM1222) in occlusal view; D. Left M2 (UNIRIOPM1224) in occlusal view. Scale $1 \mathrm{~mm}$. E. Geographic Distribution of Marmosa murina. Gray area is its extant geographic distribution. Black star marks the Gruta dos Moura cave locality. (Gardner 2008, Winge 1893, Salles et al. 1999, Cartelle 1999).

shallow and displaced anteriorly. The preparacrista is very elongated. The metacone is much larger than the paracone. The anterior cingulum is very narrow. The $\mathrm{StE}$ is poorly developed in some specimens but evident in others, and the StA is conspicuous. The $\mathrm{StB}$ is small. There is also evidence of a vestigial metaconule. The centrocrista is $\mathrm{V}$-shaped.

Comments: The upper molars have more welldeveloped StD than the living specimens. The postmetacrista is well-developed. The metacone is much larger than the paracone. Some molar teeth have a small StC. The metaconule may be present. When compared with Didelphis, M. brevicaudata has less inflated cusps and well developed styles. Compared with Marmosa, the preparacrista is proportionally larger. The StD and StB are better developed. It differs from Micoureus, which do not has the anterolabial cingulum connected to the preprotocrista, and by the conspicuous difference between the paracone and the metacone. It differs from Thylamys because the latter has mesio-distally quite compressed molars and has less developed stylar cusps.

Fossil Record in South America: This is the first fossil record of M. brevicaudata (Fig. 5).

Ecology: M. brevicaudata is more abundant in multistratal evergreen forests than in dry deciduous forest, but may be found in edge habitats around clearings (Gardner 2008). 
Monodelphis domestica (J. A. Wagner, 1842)

(Fig. 5 E-H)

Reffered material: UNIRIO-PM1100, right M1; UNIRIO-PM1101, right M1; UNIRIO-PM1102, left M1; UNIRIO-PM1103, left M1; UNIRIO-PM1104, left M1; UNIRIO-PM1105, left M1; UNIRIOPM1106, right M2; UNIRIO-PM1107, left M2; UNIRIO-PM1108, left M2; UNIRIO-PM1109, left M1; UNIRIO-PM1110, right M1; UNIRIO-PM1111, right maxillary with M2; UNIRIO-PM1112, left maxillary with M1-2; UNIRIO-PM1113, left maxillary with M1; UNIRIO-PM1114, left maxillary with M1; UNIRIO-PM1115, left maxillary with M2; UNIRIO-PM1233, right maxillary with M23; UNIRIO-PM1234, right M1; UNIRIO-PM1235, right M1; UNIRIO-PM1236, right M1.

Description: Upper molar with a quite developed and conical StD; in some molars, it is larger than the metacone. It is important to point out this feature, since this stylar cusp is much better developed when compared to living specimens. The M1 is smaller than the M2 and M3, and much more labio-lingually compressed. The ectoflexus is marked but shallow. The preparacrista is very long. The metacone is much larger than the paracone. The anterior cingulum is present. The StE is poorly developed in some specimens but evident in others; the $\mathrm{StA}$ is conspicuous. The $\mathrm{StB}$ is similar in size to paracone. The M1 also presents a vestigial metaconule. The protocone of the M1 is mesiodistally broader when compared with the M3 and M2. The centrocrista is V-shaped.

Comments: Upper molar teeth with broad protocone, paracone and metacone fairly separated and considerably different in size, where the paracone is very small. The StB and the StD are well developed at the M1-3. The StD is the largest cusp, and is very tall and conical. The upper molars are a little antero-posteriorly compressed and do not have the preprotocrista connected to the anterior cingulum. The StC is absent or much reduced. The postmetacrista is well developed and the stylar shelf is broad and deep. The ectoflexus is marked. Compared with Didelphis, it has less inflated cusps and styles B and D more developed. Compared with Marmosa, the preparacrista is proportionally larger. The StD is larger. It differs from Micoureus in the absence of the anterior cingulum connected to the preprotocrista, and for the great difference in size between the paracone and the metacone. $M$. domestica differs from Thylamys, which presents molars mesio-distally compressed, and less developed stylar cusps. It differs from M. glirina, because the latter has the StD of the M3 slightly smaller and with round border, and the StE is less evident. M. touan has smaller StD and StB. The trigone basin is less deep. $M$. iheringi presents smaller molars when compared with $M$. domestica. The StD and StB have similar sizes and are smaller when compared with $M$. domestica. M. emiliae has $\mathrm{StB}$ and $\mathrm{D}$ of similar sizes. The StB is the largest cusp of the M2 and M3. M. americana has a smaller masticatory apparatus when compared with $M$. domestica. The StB and StD are developed and of similar sizes. The StB is the largest cusp at the M2 and M3. M. domestica differs from $M$. theresa for having larger molars. The StD and B are poorly developed. $M$. scalops is smaller and has mesio-distally broader molars. M. brevicaudata has the StD subdivided in two cusps. M. umbistrick is smaller. The StD and StB have similar sizes. $M$. dimidiata has smaller molars when compared with $M$. domestica. The StD is smaller than the StB at the M3. M. kunsi has StB larger than the StD.

Fossil Record in South America: Pleistocene of Lagoa Santa, Minas Gerais and Bahia; Quaternary of Serra da Mesa, Goiás, Brazil (Winge 1893, Salles et al. 1999, Cartelle 1999) (Fig. 5).

Remarks: Monodelphis domestica is most abundant in Paraguay, Bolivia, and in Mato Grosso and northeast of Brazil, with only scattered records in central Brazil. 

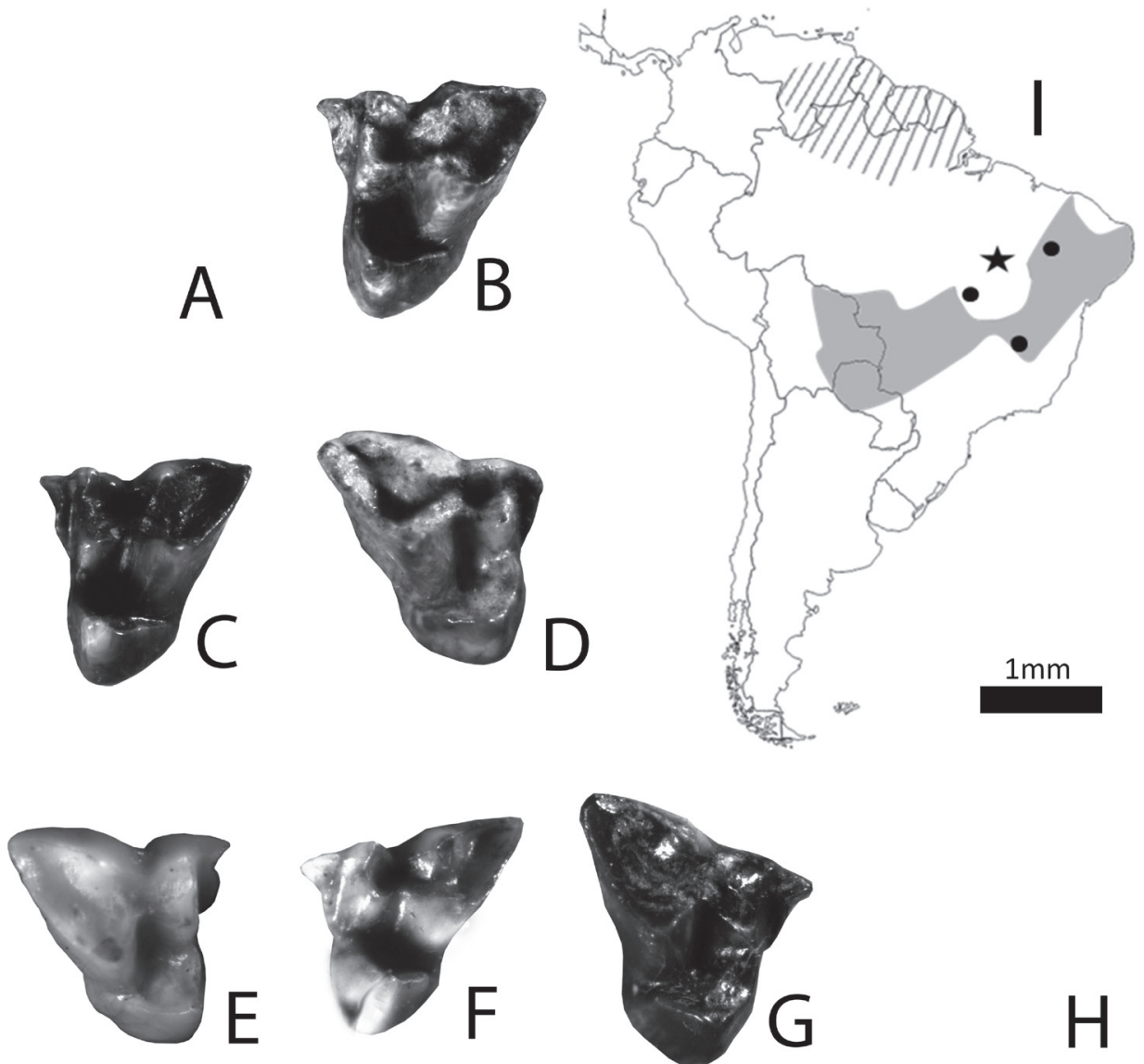

Figure 5 - Selected specimens of Monodelphis from Gruta dos Moura and its revised geographic distribution for the Pleistocene. A. Monodelphis brevicaudata left M2 (UNIRIO-PM1099) in occlusal view; B. M. brevicaudata left M1 (UNIRIO-PM1097) in occlusal view; C. M. brevicaudata left M2 (UNIRIO-PM1230) in occlusal view; D. M. brevicaudata right M1 (UNIRIO-PM1098) in occlusal view; E. Monodelphis domestica right M3 (UNIRIO-PM1233) in occlusal view; F. M. domestica left M1 (UNIRIO-PM1102) in occlusal view; G. M. domestica right M1 (UNIRIOPM1101) in occlusal; H. M. domestica right M1 (UNIRIO-PM1110) in occlusal view. Scale 1mm. I. Geographic distribution of M. brevicaudata and M. domestica. Gray area is the geographic distribution of the extant $M$. domestica. Area with vertical lines is the geographic distribution of the extant M. brevicaudata. Black star marks the Gruta dos Moura cave locality. Black circles mark Pleistocene records of M. domestica. (Gardner 2008, Winge1893, Salles et al. 1999, Cartelle 1999).

Sairadelphys Oliveira, Villa Nova, Goin \& Avilla, 2011

Sairadelphys tocantinensis Oliveira, Villa Nova, Goin \& Avilla, 2011

Hypodygm: DGEO-UFPE 6745, incomplete left maxillary with M2-4; DGEO-UFPE 6746, left m1. Diagnosis: Very small Didelphidae, slightly larger than Hyladelphys. The stilar cusps are reduced in number and size. The M2 is subequal or slightly larger than the M3. The first inferior molar has welldeveloped pre-fossid. S. tocantinensis differs from Hyladelphys for having more bunodont teeth, deeper ectoflex at the M2, paracone and metacone of similar sizes at the M2-3, very short and eccentric protocone, anterior cingulum absent, great reduction in number and size of the stilar cusps forte, and small M4. 
Description: the M2 is the largest known molar (the M1 is unknown); M2 $>$ M3 $>$ M4 . The ectoflex is well developed and symmetrical, so that the parastilar and metastilar regions are very conspicuous. The cusps of the trigone are short and bunodonts. The stylar shelf is taller than the basin of the trigone. The stylar cups are absent; there is only a vestige of $\mathrm{StD}$ at the M2. The preparacrista is short and poorly developed. The postmetacrista is slightly longer than the preparacrista. The left $\mathrm{m} 1$ has low, slightly inflated cusps. The trigonid is similar in length to the talonid. The protoconid is the largest cusp of the trigonid. The metaconid is labio-lingually compressed. It has a well developed pre-fossid.

Remarks: Sairadelphys tocantinensis was a very small marsupial comparable in dental dimensions to some of the smallest living didelphimorphians such as Hyladelphys and Gracilinanus. The upper molar morphology of Sairadelphys includes relatively low crowns, reduced M4, absence of shearing cristae and reduction of protocones. These features are suggestive of insectivorousfrugivorous feeding habits. Hyladelphys has more developed posmetacristae than Sairadelphys, which is suggestive of a more insectivorous diet (Oliveira et al. 2011).

\section{DISCUSSION}

The stratigraphically controlled survey of the described material ensures that all the specimens from Gruta dos Moura cave partially represents the diversity of didelphids that synchronously inhabited the area nearby the cave. We assume that this is a partial diversity because there are few paleontological studies which could certify that the assemblage of a given cave represents the mammal diversity of a region, since the fossilization is a rare process which depends on several factors, especially the taphonomic factors. Therefore, the calcareous block where the marsupial fossil remains were found, belongs to the same stratigraphic level throughout one of the secondary tunnels of Gruta dos Moura cave. The sedimentological features, such as color and granulometry, also suggests that the calcareous blocks had the same genesis (Avilla et al. 2013). Furthermore, the disintegration of the block revealed that there was a taphonomic selection by size, where only fragments of small vertebrates, especially mammals, including rodents (Tobelem et al. 2013), bats (Avilla et al. 2013) and marsupials (Villa Nova and Avilla 2013), were preserved. The only exception was a fragment of a maxillary bone with an almost complete toothrow of a tayassuid Catagonus stenocephalus, an extinct species from the South American Pleistocene which dates from 22.000 years before present (YBP; Eletron Spin Ressonance; Avilla et al. 2013) which was found in association with the marsupial assemblage studied here. In accordance, we also believe here that this dating is suitable to all the fossil found in the calcareous blocks of the secondary tunnel of Gruta dos Moura cave. Thus, the diversity of didelphids described here represents part of the fauna that inhabited the region around the Gruta dos Moura cave during the Last Glacial Maximum (LGM). The LGM occurred at approximatedly 22.000 YBP, and represents the coldest and drier period of South America of the last million years.

The total diversity of marsupials of Gruta dos Moura cave represents eight taxa which is the largest diversity of this group from a single Brazilian cave (Table I). Here we report the first fossil record of the following species: Didelphis aurita, Marmosa murina and Monodelphis brevicaudata. Moreover, our material is the only assemblage that securely belongs to the late Pleistocene. The other Brazilian fossil assemblages (Table I) were recovered from several caves that do not have absolute datings, preventing us from comparing those assemblages with our study.

Hitherto, the stratigraphically controlled survey of the fossils from the Gruta dos Moura cave reinforce our paleoclimatic and paleoenvironmental interpretations based on the didelphid fauna. 
TABLE I

List of didelphidae species from the PleistoceneHolocene of Brazil taken from Cartelle (1999), Salles et al. (1999) and Hadler et al. (2009).

\begin{tabular}{l|c|c|c|c|c|c}
\hline Species & TO & BA & CE & MG & GO & RS \\
\hline Caluromys lanatus & & & & $\mathrm{X}$ & & \\
\hline Cryptonanus sp. & & $\mathrm{X}$ & & & & \\
\hline Didelphis albiventris & $\mathrm{X}$ & $\mathrm{X}$ & $\mathrm{X}$ & $\mathrm{X}$ & $\mathrm{X}$ & \\
\hline Didelphis aurita & $\mathrm{X}$ & & & & & \\
\hline Didelphis marsupialis & & & & $\mathrm{X}$ & & \\
\hline Gracilinanus agilis & $\mathrm{X}$ & $\mathrm{X}$ & & $\mathrm{X}$ & $\mathrm{X}$ & $\mathrm{X}$ \\
\hline Gracilinanus emiliae & & & & & $\mathrm{X}$ & \\
\hline Gracilinanus microtarsus & $\mathrm{X}$ & & & $\mathrm{X}$ & & $\mathrm{X}$ \\
\hline Lutrolina crassicaudata & & & & $\mathrm{X}$ & & \\
\hline Marmosa grisea & & & & $\mathrm{X}$ & & \\
\hline Marmosops incanus & & & & $\mathrm{X}$ & & \\
\hline Marmosa murina & $\mathrm{X}$ & & & & & \\
\hline Marmosa pusilla & & & & $\mathrm{X}$ & & \\
\hline Marmosa velutina & & & & $\mathrm{X}$ & & \\
\hline Micoureus cinereus & & $\mathrm{X}$ & & $\mathrm{X}$ & & \\
\hline Micoureus demerarae & & & & & $\mathrm{X}$ & \\
\hline Monodelphis brevicaudata & $\mathrm{X}$ & & & & & \\
\hline Monodelphis americana & & & & & & $\mathrm{X}$ \\
\hline Monodelphis domestica & $\mathrm{X}$ & $\mathrm{X}$ & & $\mathrm{X}$ & $\mathrm{X}$ & \\
\hline Monodelphis kunsi & & & & & $\mathrm{X}$ & \\
\hline Philander opossum & & & & $\mathrm{X}$ & $\mathrm{X}$ & $\mathrm{X}$ \\
\hline Thylamys velutinus & & & & & & $\mathrm{X}$ \\
\hline Sairadelphys tocantinensis & $\mathrm{X}$ & & & & & \\
\hline & & & &
\end{tabular}

The association of the described didelphids with a specimen of Catagonus stenocephalus suggests a profusion of open areas under a dry climatic regime around the Gruta dos Moura cave (Avilla et al. 2013), different from the humid Cerrado present nowadays (Zampaulo and Ferreira 2009). Peccaries of the genus Catagonus have several morphological features associated with cursorial habits in relatively open and dry environments (e.g. orbits located in posterodorsal position and behind the M3 due to elongation of the rostrum, pronounced development of nasal sinuses and chambers, infraorbital foramen located anteriorly to the zygomatic arch, a distinct basicranial flexure, and reduction of the lateral digits of the limbs (Wetzel 1977, Gasparini et al. 2009, 2010). This also corroborates the presence of a dry climate during the LGM, where the didelphids and C. stenocephalus inhabited the region around the Gruta dos Moura cave.
Since the described diversity of didelphids are represented mostly of extant taxa, we could also infer paleoenvironmental and paleoclimatic settings for this fossil assemblage. Pleistocene faunas of small mammals, which include fossilized specimens of extant fauna, have been used as an important parameter to infer past environments and climates (Avilla et al. 2007). Therefore, as most of the taxa here identified are characteristic of open forests and gallery forests, this could have been the landscape around the Gruta dos Moura cave during the late Pleistocene. This also includes the taxa typical of humid forests, such as D. aurita, $G$. microtarsus and $M$. brevicaudata, since these taxa have been recorded on transition areas and drier regions. The gallery forests and capons from the Cerrado biome might have relict fauna from humid environments (Geise and Astúa 2009, Geise et al. 2013). Furthermore, other paleontological studies performed at the Gruta do Urso cave, nearby Gruta dos Moura cave, have fossil fauna from the same age (with datings of 25,000 to 22,000 YBP). The fauna from Gruta do Urso cave suggests an intimate association with dry open environments with high abundance of water sources (Castro et al. 2013, Hsiou et al. 2013). Among this fauna, we highlight several pampean mammals (Castro et al. 2013), capybaras (Hydrochoerus hydrochaeris), alligators (Caiman sp.) and anacondas (Eunectes murinus, Hsiou et al. 2013). However, the current climatic and environmental conditions (humid Cerrado) of the region are certainly different from those during the LGM, when the didelphid fauna described here inhabited the region. This is also evident from the record of living didelphids in other Brazilian biomes, especially in humid biomes adjacent to the Cerrado, and that are present at the fossil fauna from Gruta dos Moura cave. This is the case of Gracilinanus microtarsus, Monodelphis brevicaudata and Didelphis aurita (Gardner 2008). These taxa suggest a hypothesis opposite to the one inferred here. The fossil didelphids from Gruta dos 
Moura cave were synchronic and inhabited an open and dry environment around the Gruta dos Moura cave. Given that those species are associated with humid forests, this would suggest that the material has a temporal mixing. Nevertheless, recent studies identified sympatry between species of dry and open environments and species of humid forests (Gracilinanus, Monodelphis e Didelphis) (Geise and Astúa 2009, Geise et al. 2013). Thus, these species could inhabit gallery forests and capons, or even ecotones, inside a drier and open environment. In addition, the presence of the extinct genus Sairadelphys might indicate that the climatic and environmental conditions changed, probably leading this taxon to its extinction.

\section{ACKNOWLEDGMENTS}

We would like to thank Anselmo Rodrigues, Wagner Moura and the staff of the Sociedade Brasileira de Espeleologia, who invited us and gave us logistic help in Aurora do Tocantins. We appreciate all help from the group involved in the prospection and collection of the material. We also thank Itati Olivares, Sérgio Maia, João Alves, Diego Astua, Eleonora Costa, Yuri Leite and Francisco J. Goin for allowing us to study the collections under their care. We are also grateful to the two anonymous reviewers. The authors also thank Conselho Nacional de Desenvolvimento Científico e Tecnológico (CNPq) (401812/2010-3, Edital MCT/CNPq No 32/2010 - Fortalecimento da Paleontologia Nacional / Edital 32/2010 - Faixa B and 552975/2011, Apoio a Projetos de Pesquisa / Chamada MCTI/CNPq No 23/2011 - Apoio Técnico para Fortalecimento da Paleontologia Nacional) for financial support.

\section{RESUMO}

Neste estudo pretende-se reconhecer a diversidade de marsupiais fósseis da Gruta dos Moura além dos seus aspectos ambientais e climáticos durante o Quaternário. Constatou-se que esta é a maior diversidade de marsupiais Pleistocênicos coletados em uma única caverna: Didelphis albiventris, D. aurita, Gracilinaus agilis, G. microtarsus, Marmosa murina, Monodelphis brevicaudata, M. domestica e Sairadelphys tocantinensis. Além disso, esses marsupiais também reúnem a única assembleia fossilífera que seguramente está associada ao Neopleistoceno. Estudos paleontológicos realizados sugerem uma íntima associação com ambientes secos, abertos e de alta profusão de recursos hídricos. Assim, como a maioria dos táxons identificados são característicos de florestas abertas e matas de galerias, essa poderia ser de fato a paisagem do entorno da Gruta dos Moura. Estudos recentes identificaram simpatria entre espécies de ambientes secos/abertos e de florestas úmidas dos táxons aqui identificados e característicos de regiões úmidas. Assim, essas espécies poderiam habitar matas de galeria e capões, ou até ecótonos, em um ambiente mais seco e aberto. Além disso, a extinção de Sairadelphys pode ser outro indício de que as condições climáticoambientais mudaram ou que $\mathrm{o}$ ambiente pretérito era mais heterogêneo que o encontrado atualmente na região.

Palavras-chave: mamíferos, Didelphidae, Marsupiais, norte do Brasil, Quaternário, Pleistoceno Superior.

\section{REFERENCES}

APLIN KP AND ARCHER M. 1987. Recent advances in marsupial systematic with a syncretic classification. In: Archer M (Ed), Possums and Opossums: Studies in Evolution. Surrey Beatty \& Sons and the Royal Zoological Society of New South Wales, Sydney, p. 15-72.

Avilla LS, Muller L, Gasparini GM, Soibelzon L, Absolon B, PÊGo FB, Silva RC, Kinoshita A, FigUEIREIDO AMG AND BAFFA O. 2013. The northernmost Record of Catagonus stenocephalus (Lund in Reinhardt, 1880) palaeobiogeographical significance. J S Am E Sci 42: 39-46.

AVILLA LS, Winck GR, FRANCISCO VMR, GIL BB AND COSTA DC. 2007. A Fauna de Morcegos fósseis como Ferramenta na Caracterização de Paleoambientes Quaternários. Anu Inst Geoc 30: 19-26.

AUlER A AND FARRANT AR. 1999. A brief introduction to karst and caves in Brazil. Proc Univ Bristol Spelaeol Soc 20(3): 187-200

Auler AS, SMART PL, WANG X, Piló LB, Edwards RL AND CHENG H. 2009. Cyclic sedimentation in Brazilian caves: mechanisms and palaeoenvironmental significance. Geomorphology 106: 142-153. 
BRAIN CK. 1995. The influence of climatic changes on the completeness of the earlyhominid record in Southern African caves, with particular reference to Swartkrans. In: Vrba ES, Denton GH, Partridge TC and Burckle LH (Eds), Paleoclimate and Evolution with Emphasis on Human Origins. Yale University Press, New Haven, p. 451-458.

Brook GA, CowArt JB, Brandt SA AND Scott L. 1997. Quaternary climatic change in southern and eastern Africa during the last $300 \mathrm{ka}$ : the evidence from caves in Somalia and the Transvaal region of South Africa. Z Geomorphol Supplement band 108: 15-48.

CARTElle C. 1999. Pleistocene mammals of the Cerrado and Caatinga of Brazil. In: Eisenberg JF and Redford KH (Eds), Mammals of the Neotropics. The University of Chicago Press, p. 27-46.

Castro mC, Avilla LS, Freitas ML and Carilini AA. 2013. The armadillo Propraopussulcatus (Mammalia: Xenarthra) from the late Quaternary of northern Brazil and a revised synonymy with Propraopusgrandis. Quatern Int 317: 80-87.

Cozzuol M, Goin FJ, Reyes M And Ranzi A. 2006. The oldest species of Didelphis (Mammalia, Marsupialia, Didelphidae), from the late Miocene of Amazonia. J Mammal 87: 663-667.

CPRM - Companhia de Pesquisa de Recursos Minerais. 2006. Rochas Carbonáticas do Grupo Bambuí na região Nordeste do Estado de Goiás. Disponível em: http:// www.cprm.gov.br/publique/cgi/cgilua.exe/sys/start. httm? infoid $1 / 4261 \& \operatorname{sid}^{1} \frac{1}{432}(5.12 .2010)$.

DARDENE MA. 1978. Síntese sobre a estratigrafia do Grupo Bambuí no Brasil Central. 30 Congresso Brasileiro de Geologia. Sociedade Brasileira de Geologia, Recife, p. 597-610.

DARdene MA AND WALDE HHG. 1979. A estratigrafia dos Grupos Bambuí e Macaúbas no Brasil Central. In: $1^{\circ}$ Simpósio de Geologia de Minas, Sociedade Brasileira de Geologia, Belo Horizonte, p. 43-54.

GARDNer AL. 2008. Mammals of South America. Vol. 1. Marsupials, xenarthrans, shrews, and bats. Chicago University Press, Chicago, p. 1-669.

Gasparini GM, Kerber L AND Oliveira E. 2009. Catagonus stenocephalus (Lund in Reinhardt, 1880) (Mammalia, Tayassuidae) in the Touro Passo Formation (Late Pleistocene), Rio Grande do Sul, Brazil. Taxonomic and palaeoenvironmental comments. Neues Jahrb Geol Paläontologie Abhandlungen 254(3): 261-273.

Gasparini GM, Soibelzon E, Zurita AE AND MiñoBoILINI AR. 2010. A review of the Quaternary Tayassuidae (Mammalia, Artiodactyla) from the Tarija Valley, Bolivia. Alcheringa. An Australas J Palaeont 1: 7-20.

Geise L, ASFora PH AND AZAMOR L. 2013. Transition area in the Brazilian Atlantic Forest: characterization of the mammal fauna in the Jequitinhonha Valley. International Mammalogical Congress.
GeISE L AND ASTÚA D. 2009. Distribution extension and sympatric occurrence of Gracilinanus agilis and $\mathrm{G}$. microtarsus (Didelphimorphia, Didelphidae), with cytogenetic notes. Biota Neotrop 9(4): 269-276.

GoIN FJ. 1995. New clues for undestanding neogene marsupial radiations. In: Kay RF, Madden RH, Cifelle RL and Flynn JJ (Eds), Vertebrate Paleontology in the Neotropics: The Miocene Fauna of La Venta, Colombia, Smithsonian Institution Press, Washington and London, p. 187-206.

GoIn FJ AND CANDELA AM. 2004. New Palaeogene marsupials from the Amazon Basin of Eastern Peril. In: CAMPBELL KE (Ed), The Paleogene mammalian fauna of Santa Rosa, Amazonian Peru. - Science Series. Natural History Museum of Los Angeles County 40: 15-60.

Hadler P, Ferigolo J AND GoIn FJ. 2009. Mamíferos de pequeno porte (Didelphimorphia, Chiroptera e Rodentia) do Pleistoceno final/Holoceno do Brasil, com ênfase no Rio Grande do Sul. In: Ribeiro AM, Bauermann S and Scherer C (Eds), Quaternário do Rio Grande do Sul: Integrando Conhecimentos. Monografias da Sociedade Brasileira de Paleontologia, Porto Alegre, p. 155-170.

Hsiou A, Winck G, Shubert B And Avilla L. 2013. On the presence of Eunectes murinus (SQUAMATA, SERPENTES) from the Late Pleistocene of Northern Brazil. Rev Bras Paleontol 16 (1): 77-82.

LUND PW. 1950. Memórias sobre a Paleontologia Brasileira, Revistas e Comentadas por Carlos de Paula Couto. Instituto Nacional do Livro, Rio de Janeiro, 589 p.

Marshall LG, CASE JA AND WoOdBuRne MO. 1990. Phylogenetic relationships of the families of marsupials. In: Genoways HH (Ed), Current Mammalogy, Vol. 2. Plenun Press, New York. p. 433-506.

OliveIRA EV AND GoIN FJ. 2006. Marsupiais do Início do Terciário do Brasil: Origem, Irradiação e História Biogeográfica. In: Marsupiais do Brasil, Cap. 22.

Oliveira EV, Villa Nova P, Goin FJ and Avilla LS. 2011. A new hyladelphine marsupial (Didelphimorphia, Didelphidae) from cave deposits of northern Brazil. Zootaxa 3041: 51-62.

PALMER AN. 1991. Origin and morphology of limestone caves. Geol Soc Am Bull 103: 1-21.

PAscual R. 1980. Prepidolopidae, una nueva familia de Marsupialia didelphoidea del Eoceno sudamericano. Ameghiniana 17: 216-242.

REIG OA, KIRSCH JAW AND MARSHALL LG. 1987. Systematic relationships of the living and Neocenozoic American 'opossum-like' marsupials (suborder Didelphimorphia), with comments on the classification of these and of the Cretaceous and Paleogene New World and European metatherians. In: Archer M (Ed), Possums and Opossums: Studies in Evolution. Surrey Beatty \& Sons and the Royal Zoological Society of New South Wales, Sydney, p. 1-89. 
SALAZAR-BRAVO JE, YeNSEN T, TARIFA AND YATES TL. 2002 Distributional records of Bolivian mammals. Mastozool Neotrop 9: 70-78.

Salles LS ET AL. 1999. Fauna de Mamíferos do Quaternário de Serra da Mesa (Goiás, Brasil). Pub Avul do Museu Nacional 78: 1-15.

TOBELEM H, Dutra RP AND AVILLA LS. 2013. Os roedores Cricetidae Sigmodontinae (Mammalia, Rodentia) do Quaternário do norte do Brasil. Bol Paleontologia em Destaque. Edição Especial XXIIICBP, p. 288.

Villa Nova P AND AVILla LS. 2013. Os marsupiais (Didelphimorphia, Mammalia) pleistocênicos do intertropical brasileiro. Bol Paleontologia em Destaque. Edição Especial XXIIICBP, p. 291.
Wetzel RM. 1977. The Chacoan peccary, Catagonuswagneri (Rusconi). Bull Carnegie Mus Nat Hist 3: 1-36.

WINGE H. 1893. Jordfundneognulevendepungdyr (Marsupialia) fra Lagoa Santa, Minas Geraes, Brasilien, 133 p.

ZAmpaulo RA AND FERREIRA RL. 2009. Terrestrial cave invertebrate diversity in nine caves in the municipality of Aurora do Tocantins (TO). Anais do $30^{\circ}$ Congresso Brasileiro de Espeleologia, Montes Claros, MG, p. 267-274. 